\begin{abstract}
Iranica
Abstracta Iranica Revue bibliographique pour le domaine irano-aryen

Volume 34-35-36 | 2017

Comptes rendus des publications de 2011-2013
\end{abstract}

\title{
Alberto Cantera (ed.). The Transmission of the Avesta
}

\section{Thomas Jügel}

\section{(2) OpenEdition \\ Journals}

Electronic version

URL: http://journals.openedition.org/abstractairanica/41130

DOI: 10.4000/abstractairanica.41130

ISSN: 1961-960X

\section{Publisher:}

CNRS (UMR 7528 Mondes iraniens et indiens), Éditions de l'IFRI

\section{Electronic reference}

Thomas Jügel, « Alberto Cantera (ed.). The Transmission of the Avesta », Abstracta Iranica [Online], Volume 34-35-36 | 2017, document 2, Online since 15 July 2016, connection on 27 September 2020. URL : http://journals.openedition.org/abstractairanica/41130 ; DOI : https://doi.org/10.4000/ abstractairanica.41130

This text was automatically generated on 27 September 2020 .

Tous droits réservés 


\title{
Alberto Cantera (ed.). The Transmission of the Avesta
}

\author{
Thomas Jügel
}

\section{REFERENCES}

Alberto Cantera (ed.). The Transmission of the Avesta. Wiesbaden, Harrassowitz, 2012, XX, 552 p. (Iranica 20)

1 This collective volume is partly the output of a symposium held in Salamanca, September 2009, with several additional articles. Articles are written in English (18), French (4), and German (1). They are sorted into four sections:

2 (A): "From the Oral Composition to the Writing down of the Avestan text": Prods O. Skjærvø analyses philologically the oral composition of the Avesta by identifying "building blocks" that were used in "(re)composition in performance". He assumes a "crystalization of the Young Avestan texts" (a fixation) for the Achaemenid period and he discusses the transmission process of the Avesta for various stages. Jean Kellens gives a survey of earlier hypotheses regarding the original edition of the Avesta and, by adding some observations, he concludes that the Yasna existed before the "idee d'Avesta". Kellens believes that the constitution of the Yasna, as we know it today, is linked to the constitution of the calendar. Ulla Remmer's contribution on the composition of the Niyāyišn, which are compilations of Young and old Avestan passages, contains several philological discussions. Antonio Panaino's contribution on the age of the Avestan Canon and the origins of the ritual written texts is partly a critical response to Kellens point of view, arguing for an early Middle Persian invention of the Avestan script and dating the Stammhandschriften of today's manuscripts to the 9th c. CE. The late Xavier Tremblay rejects Hoffmann's idea of a single archetype of the Avesta. Concerning the textualisation ("mise par écrit"), he investigates Pahlawi, Manichaean, and Syriac evidence, arriving at a date between 550-630 CE. The article 
concludes with a philological argumentation for a multiplicity of archetypes. Éric Pirart offers a detailed analysis of the Avestan metric.

(B): "The Manuscripts and their Analysis": Katayoun Mazdapour presents twelve newly found Avestan manuscripts in Iran, and Ursula Sims-Williams 42 Zoroastrian manuscripts in the British library in London including several facsimiles and valuable information on the collectors and their collections. Fateme Jahanpour presents one Wīdēwdād (Vendidad) manuscript of the Astan-Qods Library. Firoze M. Kotwal provides information on the first Dastoor Meherjirana Library in Navsari. Miguel Ángel AndrésToledo and Alberto Cantera present lists of the Wīdēwdād manuscripts that are available today and of those whose location is unknown, altogether 230 manuscripts of various categories (Indian/Iranian, Sāde/Pahlawi, etc.). Almut Hintze presents 178 manuscripts of the Yasna and the Yasna i Rapithwin.

The analysis section is opened up with an article, $68 \mathrm{p}$. long, on the new methodology in stemmatology by Alberto Cantera. He outlines in detail typological features of the Wìdēwdād manuscripts and discusses their genealogy. The question of Stammhandschrift and archetypes is addressed once again. In contrast to the previous articles, Cantera discusses the matter as far as it concerns the existant manuscripts. In a combination of a philological analysis and a computer-based method, Cantera calculates the "pregenealogical coherence". Taking then external data into account like colophones, paleography and codicology, he produces various stemmata of "genealogical coherence" as an example of his method.

Jaime Martínez Porro applies Cantera's methodology to the manuscripts of the family of L4. Götz König begins his article on the Nask bayān and the Xorde Avesta by elucidating the importance of Cantera's new methodology for Avestan studies. His article focusses on two questions: whether the Xorde Avesta was part of the "Hochamtszeremonien" and whether the use of the term 'Xorde Avesta' is consistent in the way it is used in research. His detailed philological analysis is supported by statistical data. Juan José Ferrer develops a typology of Avestan citations in the Pahlawi translation of Wīdēwdād Sāde manuscripts including several facsimile excerpt. By interpreting varitions among manuscripts, he concludes that liturgic and exegetic manuscripts were collated more than once.

6 (C): "The Edition of the Avesta": Almut Hintze gives a detailed survey of the up to date editing projects of the Avesta and their methods. Miguel Ángel Andrés-Toledo offers a critical discussion of Geldner's Avesta edition, which is meant as a justification for the necessity of a new revised edition. This point is taken up by Alberto Cantera in the following article: Why do we really need a new edition of the Zoroastrian long liturgy? Cantera answers this question by discussing several shortcomings of previous approaches and the pros \& cons of diplomatic and eclectic editions in detail. He highlights the importance of Karl Hoffmann's new methodology, but emphasises the value of text-critical analysis.

7 (D): "The Transmission and Edition of Other Zoroastrian Texts": Kianoosh Rezania analyses the relevance of Mazdakism for the canonisation of the zand, the Pahlawi translation of the Avestan texts. He considers the canonisation of the zand as a reaction of the establishment to an inner-Zoroastrian reform movement. Götz König reviews the hypothesis of 'claimed loss of translatory tradition' using the example of Yašt 14 and explicates the insight an imperfect Pahlawi translation has to offer. Maria Macuch outlines the relevance of the zand for the study of Zoroastrian jurisprudence and vice 
versa. This is exemplified by the philological discussion of adwadād "shortage of supplies (etc.)". The contribution of Judith Josephson on the evolution and transmission of Dēnkard 3 identifies principles of logic in the text and comments on linguistics features like the use of the relative particle or the nominal style.

8 This collective volume gives a comprehensive overview of current projects on editing Avestan. It is a treasure of in-depth philological discussions, which are as illuminating as they are instructive. Several topics (like archetypes and Stammhandschriften or the relation of written and oral transmission) run like a common thread through many contributions, and the opposing opinions expressed by several authors mirror the ongoing discussion and make the reading of this book an exciting task.

\section{AUTHORS}

THOMAS JÜGEL

Mondes iranien et indien, Paris 